\section{УДК 633.2.033.4}

https://doi.org/10.32634/0869-8155-2021-348-4-75-78

Краткий обзор/Brief review

Кадоркина В.Ф.,

Шевцова М.С.

ФГБНУ «Научно-исследовательский институт аграрных проблем Хакасии", Усть-Абаканский район, с. Зеленое, ул. Садовая, д. 5 E-mail: qeenmaria@yandex.ru

Ключевые слова: ломкоколосник ситниковый, биотипы, укосы, питательность, исходный материал

Для цитирования: Кадоркина В.Ф., Шевцова М.С. Оценка биотипов ломкоколосника ситникового (Psathyrostachys juncea (Fisch)) при многоукосном использовании. Аграрная наука. 2021; 348 (4): 75-78.

https://doi.org/10.32634/0869-8155-2021-348-4-75-78

Конфликт интересов отсутствует

Vera F. Kadorkina,

Maria S. Shevtsova

FSBNU "Research Institute of Agrarian Problems of Khakassia", Ust-Abakan district, s. Green, st. Sadovaya, 5 qeenmaria@yandex.ru

Key words: slash grate, biotypes, bumps, nutritivity, starting materia

For citation: Kadorkina V.F., Shevtsova M.S. Assessment of biotypes of the Russian wildrye (Psathyrostachys juncea (Fisch)) with multislope use. Agrarian Science. 2021; 348 (4): 75-78. (In Russ.)

https://doi.org/10.32634/0869-8155-2021-348-4-75-78

There is no conflict of interests

\title{
Оценка биотипов
}

\section{ломкоколосника ситникового (Psathyrostachys juncea (Fisch)) при многоукосном}

\section{использовании}

\begin{abstract}
PEЗЮME
Приведены результаты многоукосного использования ломкоколосника ситникового в питомнике исходного материала и данные о его питательности. Питомник исходного материала заложен в 2015 году, гнездовым способом, на территории ботанического сада НИИ аграрных проблем Хакасии в количестве 26 образцов. Работа проведена в соответствии с методическими указаниями по селекции многолетних злаковых трав, селекции и семеноводству многолетних трав. Наблюдения за ростом и развитием растений, учет продуктивности изучаемых номеров проводили по правилам селекции кормовых трав в Сибири. При оценке этой культуры для пастбищного использования проводили четыре скашивания. Характеризующее значение имеет не столько абсолютная величина прироста отавы, сколько его относительная стабильность в течение вегетационного периода. По сумме четырех укосов наибольшая продуктивность зеленой массы отмечена у $\mathrm{K}$ 1, K 2, K 3, K 5, К 6, K 9, K 18 - от 500 г до 720 г. Мощность травостоя после стравливания является одним из показателей, определяющих нормальное состояние и развитие растений. После четырехкратного скашивания высокую мощность куста имели номера К 1, К 2, K 3, К 5, K 6, К 9, K 18 - от 3,6 до 4,6 балла. По основному укосу по кормовым единицам выделились К 1 , K 2 - 0,69-0,69 кг корма (стандарт $-0,49$ кг) и при отаве $-0,68-0,67$ кг (стандарт - 0,49 кг), соответственно по переваримому протеину по основному укосу К $1-149,6$, К 2 - 162,5 г/кг корма стандарт 141,1 г/кг и K 1 - 147,2, К 2 - 140,2 (стандарт - 140,0 г/кг корма); по обменной энергии по основному укосу К 1 и К 2 9,8 МДж и 10,0 МДж, стандарт Манчаары 9,7 МДж.
\end{abstract}

\section{Assessment of the biotypes of the Russian wildrye (Psathyrostachys juncea (Fisch)) with multislope use}

\begin{abstract}
The article presents the results of the multi-scale use of the Russian wildrye in the nursery of the source material and research on its nutritional value. The nursery of the source material was laid in 2015 by nesting method on the territory of the botanical garden "Research Institute of Agricultural Problems of Khakassia" in the amount of 26 samples. The work was carried out in accordance with the guidelines for the selection of perennial cereal grasses, selection and seed production of perennial grasses. Observations of the growth and development of plants, accounting of the productivity of the studied varieties were carried out on the selection of forage grasses in Siberia. When evaluating this culture for pasture use four mowing operatios were carried out. The characteristic value is not only the absolute value of the growth of the crop, but its relative stability of regrowth during the growing season. According to the sum of the four mows, the highest productivity of the green mass was observed in $\mathrm{K} 1, \mathrm{~K} 2, \mathrm{~K} 3, \mathrm{~K} 5, \mathrm{~K} 6, \mathrm{~K} 9$, and $\mathrm{K} 18$ from $500 \mathrm{~g}$ to $720 \mathrm{~g}$. The capacity of the grass stand after grazing is one of the indicators that determine the normal state and development of plants. After four - fold mowing the numbers $\mathrm{K} 1, \mathrm{~K} 2, \mathrm{~K} 3, \mathrm{~K} 5, \mathrm{~K} 6, \mathrm{~K} 9$, and $\mathrm{K} 18$ had a high bush power-from 3.6 to 4.6 points. For the main mowing, forage units were allocated to 1 , To $2-0,69-0,69 \mathrm{~kg}$ of feed standard $0.49 \mathrm{~kg}$ and at otave $0.68-0.67 \mathrm{~kg}$, standard $0.49 \mathrm{~kg}$, respectively, for digestible protein To $1-149.6$, To $2-162.5 \mathrm{~g} / \mathrm{kg}$ of feed standard $141.1 \mathrm{~g} / \mathrm{kg}$ and to 1 -147.2 , to $2-140.2$, standard $140.0 \mathrm{~g} / \mathrm{kg}$ of feed) and for exchange energy for the main mowing to 1 and $29.8 \mathrm{MJ}$ and $10.0 \mathrm{MJ}$, standard (Manchaara) $-9.7 \mathrm{MJ}$.
\end{abstract}




\section{Введение}

Формы, обладающие исключительными адаптивными и продуктивными характеристиками в местных условиях, могут быть улучшены дальнейшей селекцией [1]. Ломкоколосник ситниковый (Psathurostachys juncea (Fisch)) - типичное пастбищное растение. От других пастбищных злаков отличается высоким содержанием протеина (13-15\%), устойчивостью к вытаптыванию, ранним отрастанием (сразу после схода снега), высокой отавностью. При использовании в ранние фазы развития (до колошения) при среднегодовом количестве осадков 230 мм дает 1-2 отавы, в сухостепном районе республики Хакасия при среднегодовом количестве осадков 280 мм дает 3-4 отавы. Для селекционеров, работающих в направлении кормопроизводства, это означает возможность создания новых сортов кормовых культур с хорошей поедаемостью и переваримостью кормовой массы при высоком содержании в ней протеина, жира, углеводов, витаминов, микроэлементов, незаменимых аминокислот [2, 3, 4, 5, 6].

Ломкоколосник ситниковый - один из видов многолетних трав для пастбищного использования, обладающий хорошей отавностью и многолетним использованием в травостое в течение 10-15 лет, пригодный к пастбищному использованию; отличается ранним весенним отрастанием, а осенью остается в зеленом состоянии и прекрасно используется как пастбищная трава $[7,8]$.

Цель исследований - оценка и отбор биотипов ломкоколосника ситникового в питомнике исходного материала на продуктивность и питательность для пастбищного направления при многоукосном использовании.

\section{Методика исследований}

Исследования проводились в 2015-2020 годах, коллекционный питомник исходного материала заложен 15 июня 2015 года в количестве 26 сортообразцов на территории ботанического сада ФГБНУ «НИИ аграрных проблем Хакасии» на каштановых почвах. За стандарт взят сорт Манчаары. В период вегетации проводились фенологические наблюдения, дана оценка мощности травостоя по пятибалльной шкале: 1 - очень низкая; 2 - низкая; 3 средняя; 4 - высокая; 5 - очень высокая. Для пастбищного использования растений закрепляли постоянные площадки на ряд лет деревянными колышками, которые находятся ниже уровня скашивания. Урожайность кормовой массы измеряли при наступлении пастбищной спелости (высота травостоя - 1520 см), в 3-4 скашивания.

Питательность кормов определялась в ФГБУ «Государственная станция агрохимической службы «Хакасская». Работа проведена в соответствии с методическими указа- ниями по селекции многолетних злаковых трав, селекции и семеноводству многолетних трав $[9,10,11,12]$ Наблюдения за ростом и развитием растений, продуктивность изучаемых номеров проводили по правилам селекции кормовых трав в Сибири, статистическую обработку данных - с использованием программы Excel [13].

Сложившиеся погодные условия за эти годы в разные периоды вегетации были относительно благоприятными для роста и развития растений. В 2018 году агрометеорологические условия были менее благоприятными для ломкоколосника ситникового. Температура воздуха во все периоды вегетации была выше среднемноголетних значений на 2-5 ${ }^{\circ} \mathrm{C}$, кроме мая и июня, когда она была в пределах нормы. Осадков выпало ниже среднемноголетних показателей [14].

Погодные условия 2019 года характеризовались достаточным увлажнением и повышенной температурой воздуха, которая была на $2-7^{\circ} \mathrm{C}$ выше нормы. Осадков за весь период развития культуры выпало 311,5 мм, что на 46,3 мм больше нормы.
Таблица 1. Продуктивность зеленой массы при четырех сроках скашивания, г $/ \mathbf{M}^{2}$, среднее за 2018-2020 rr.

Table 1. Productivity of green mass at four mowing periods, $\mathbf{g} / \mathrm{m}^{2}$, from average 2018-2020

\begin{tabular}{|c|c|c|c|c|c|c|c|c|c|c|}
\hline \multirow{2}{*}{$\begin{array}{l}\text { Сорто- } \\
\text { образцы }\end{array}$} & \multicolumn{4}{|c|}{ Высота растений, см } & \multicolumn{5}{|c|}{ Продуктивность зеленой массы, г/м² } & \multirow{2}{*}{$\begin{array}{c}\text { Мощность } \\
\text { травостоя после } \\
\text { 4-ого укоса, } \\
\text { в баллах }\end{array}$} \\
\hline & 1-й & 2-й & 3-й & 4-й & 1-й & 2-й & 3-й & 4-й & Сумма & \\
\hline K 1 & 27,0 & 28,8 & 27,8 & 28,0 & 297 & 193 & 115 & 75 & 680 & 4,3 \\
\hline K 2 & 28,0 & 32,4 & 30,4 & 29,3 & 343 & 172 & 150 & 55 & 720 & 4,6 \\
\hline K 3 & 20,5 & 31,5 & 28,4 & 27,8 & 347 & 126 & 105 & 80 & 637 & 4,6 \\
\hline K 4 & 21,5 & 30,4 & 29,7 & 26,4 & 213 & 97 & 55 & 25 & 390 & 3,0 \\
\hline K 5 & 36,0 & 31,5 & 30,0 & 30,5 & 283 & 93 & 75 & 60 & 511 & 4,3 \\
\hline K 6 & 24,0 & 32,7 & 28,0 & 31,0 & 250 & 123 & 100 & 60 & 533 & 3,9 \\
\hline $\mathrm{K} 7$ & 29,9 & 33,4 & 30,0 & 30,5 & 170 & 67 & 50 & 30 & 317 & 2,0 \\
\hline K 8 & 28,0 & 30,7 & 28,2 & 29,6 & 153 & 80 & 80 & 35 & 348 & 3,0 \\
\hline K 9 & 29,5 & 29,3 & 29,0 & 30,0 & 187 & 103 & 80 & 55 & 425 & 3,6 \\
\hline K 10 & 28,0 & 30,0 & 29,7 & 30,0 & 213 & 93 & 40 & 10 & 356 & 2,3 \\
\hline K 11 & 27,4 & 29,0 & 30,1 & 30,5 & 213 & 93 & 45 & 30 & 381 & 2,4 \\
\hline K 12 & 28,2 & 31,1 & 30,1 & 30,8 & 190 & 77 & 45 & 40 & 352 & 3,0 \\
\hline K 13 & 30,1 & 30,4 & 30,0 & 29,0 & 183 & 83 & 80 & 35 & 381 & 2,2 \\
\hline K 14 & 27,5 & 28,9 & 31,0 & 31,0 & 180 & 57 & 55 & 35 & 327 & 2,1 \\
\hline K 15 & 26,5 & 30,6 & 32,0 & 28,7 & 120 & 46 & 40 & 25 & 231 & 1,0 \\
\hline K 16 & 26,8 & 30,0 & 31,9 & 31,5 & 170 & 53 & 35 & 20 & 278 & 1,6 \\
\hline K 17 & 27,0 & 31,2 & 29,5 & 30,5 & 30 & 25 & 20 & 20 & 95 & 1,4 \\
\hline K 18 & 27,9 & 30,7 & 29,0 & 29,9 & 263 & 107 & 80 & 35 & 505 & 3,6 \\
\hline K 19 & 29,6 & 33,6 & 31,2 & 31,2 & 176 & 43 & 40 & 35 & 294 & 2,6 \\
\hline K 20 & 24,5 & 28,9 & 31,6 & 32,0 & 186 & 70 & 65 & 30 & 351 & 1,4 \\
\hline K 21 & 29,6 & 30,2 & 30,6 & 31,0 & 186 & 86 & 60 & 35 & 367 & 1,6 \\
\hline K 22 & 28,9 & 31,0 & 28,9 & 30,5 & 120 & 60 & 35 & 15 & 230 & 1,4 \\
\hline K 23 & 31,6 & 30,3 & 30,5 & 29,5 & 220 & 60 & 60 & 25 & 365 & 3,3 \\
\hline K 24 & 30,5 & 30,0 & 28,8 & 30,2 & 153 & 56 & 35 & 20 & 264 & 1,2 \\
\hline K 25 & 28,9 & 31,5 & 28,9 & 30,5 & 166 & 35 & 30 & 25 & 256 & 1,6 \\
\hline K 26 & 27,5 & 29,8 & 28,8 & 30,0 & 103 & 45 & 45 & 20 & 213 & 1,2 \\
\hline
\end{tabular}


Температурный режим за вегетационный период 2020 года был выше среднемноголетнего значения, данный год характеризовался неравномерным выпадение осадков, в июне выпало осадков в 4,2 раза больше нормы, июль и август соответствовал и нормам.

\section{Результаты исследований}

Для пастбищных целей особую ценность представляют сортообразцы ломкоколосника ситникового с хорошей отавностью. Его особенностью как лугопастбищной культуры является равномерность распределения кормовой массы в зависимости от укосов. Повторное, многократное удаление ассимилирующего аппарата - надземных побегов вместе с зелеными листьями - могут перенести лишь биотипы, обладающие большой способностью к вегетативному возобновлению, способные к отрастанию с образованием отавы.

Фенологические наблюдения за ростом и развитием 26 биотипов в 2018-2020 гг. в питомнике исходного материала показали, что начало весеннего отрастания у сортообразцов К 1, К 2, К 3, К 6, К 12, К 18 наблюдалось в конце третьей декады апреля, а у остальных образцов - на неделю позже, высота растений составила 2,5-5,8 см. Основной укос изучаемых образцов наступил в третей декаде мая, с высотой растений от 20,5 до 36,0 см. Последующие скашивания проходили через 13-22 дня. При оценке образцов характеризующее значение имеет не столько абсолютная величина прироста отавы, сколько его относительная стабильность в течение вегетации в последующие годы (табл. 1).

За годы исследований при оценке этой культуры для пастбищного использования проведили четыре скашивания.

При первом скашивании растений в питомнике исходного материала по продуктивности сырой массы выделены образцы К 1, К 2, К 3, К 4 K 5, K 6, K 9, K 10, K 11, K 12, K 18, K 20, K 21, K 23 (185-347 г/м²). При втором укосе - номера K 1 , K 2, K 3 , K 6, К 9, К 18 (100-193 г/м²), при третьем скашивании сортообразцы К 1, К 2, К 3, К 6 имели от 100 до 155 г/м² и при четвертом K 1 , K 3, К 5 , К $6-60-80 г / \mathrm{M}^{2}$. По сумме четырех укосов наибольшая урожайность зеленой массы отмечена у К 1 , К 2, К 3 ,

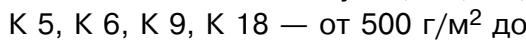
$720 \mathrm{r} / \mathrm{M}^{2}$.

Мощность травостоя после стравливания является одним из показателей, определяющих нормальное состояние и развитие растений После четырехкратного скашивания высокую мощность куста имели номера K $1, \mathrm{~K} 2, \mathrm{~K} 3, \mathrm{~K} 5, \mathrm{~K} 6, \mathrm{~K} 9, \mathrm{~K} 18$ от 3,6 до 4,6 балла, остальные - 3,3 балла (от средней и до очень низкой).
Критерием оценки зеленой массы при четырех сроках скашивания могут быть разные статистические показатели: дисперсия признаков, характер распределения частот и др. Статистические данные по продуктивности зеленой массы 26 сортообразцов в питомнике исходного материала в различные сроки скашивания приведены в табл. 2.

Коэффициент вариации дает возможность сравнить изменчивость признака продуктивности зеленой массы сортообразцов. Установлено, что изменчивость признака зеленой массы существенная (CV > 30), составляет 41,68-55,60\% при четырех сроках скашивания.

Ломкоколосник ситниковый содержит максимальное количество питательных веществ в ранние фазы развития [5]. Кормовая ценность выделенных образцов определялась при двух укосах зеленой массы: основной (в фазу кущения 2/VI) и отава (выход в трубку 5/VII). По

Таблица 2. Продуктивность зеленой массы ломкоколосника ситникового при четырех сроках скашивания в питомнике исходного материала, 2018-2020 гг.

Table 2. Productivity of the green mass of the Russian wildrye at four terms of mowing in the nursery of the source material, 2018-2020

\begin{tabular}{|c|c|c|c|c|c|}
\hline \multirow{2}{*}{ Признак } & \multirow{2}{*}{$\begin{array}{c}\text { Пределы варьи- } \\
\text { рования }\end{array}$} & \multicolumn{3}{|c|}{ Популяция } & \multirow{2}{*}{$\begin{array}{l}\text { Коэффициент } \\
\text { вариации, V, \% }\end{array}$} \\
\hline & & $\overline{\mathbf{x}}$ & $S \bar{x}$ & s & \\
\hline $\begin{array}{l}\text { Зеленая масса } \\
\text { 1-го укоса }\end{array}$ & $30,0-347,0$ & 185,9 & 14,64 & 77,5 & 41,68 \\
\hline $\begin{array}{l}\text { Зеленая масса } \\
\text { 2-го укоса }\end{array}$ & $25,0-193,0$ & 78,86 & 7,70 & 40,98 & 51,96 \\
\hline $\begin{array}{l}\text { Зеленая масса } \\
\text { 3-го укоса }\end{array}$ & $20,0-150,0$ & 60,81 & 6,30 & 32,5 & 53,50 \\
\hline $\begin{array}{l}\text { Зеленая масса } \\
\text { 4-го укоса }\end{array}$ & $10,0-80,0$ & 33,82 & 3,55 & 18,8 & 55,60 \\
\hline
\end{tabular}

Примечание. $\overline{\mathrm{x}}$ - среднее арифметическое значение; $\mathrm{S} \overline{\mathrm{x}}$ - ошибка средней; S - стандартное отклонение

Таблица 3. Питательная ценность зеленой массы сортообразцов ломкоколосника ситникового в питомнике исходного материала, 2019-2020 гг.

Table 3. The nutritional value of the green mass of the variety samples of the Russian wildrye in the nursery of the source material, 2019-2020

\begin{tabular}{|c|c|c|c|c|}
\hline \multirow{2}{*}{ Образец } & \multicolumn{4}{|c|}{ Содержится в 1 кг корма } \\
\hline & $\begin{array}{c}\text { Кормовые единицы, } \\
\text { кг }\end{array}$ & $\begin{array}{c}\text { Переваримый } \\
\text { протеин, г }\end{array}$ & Клетчатка, г & ОЭ, мДж \\
\hline \multicolumn{5}{|c|}{ Основной укос } \\
\hline St. Манчаары & 0,49 & 141,1 & 297,7 & 9,7 \\
\hline K 1 & 0,69 & 149,6 & 291,1 & 9,8 \\
\hline K 2 & 0,69 & 162,5 & 275,5 & 10,0 \\
\hline K 7 & 0,69 & 118,3 & 295,2 & 9,7 \\
\hline K 9 & 0,70 & 130,4 & 293,3 & 9,7 \\
\hline K 12 & 0,68 & 109,0 & 304,6 & 9,5 \\
\hline K 18 & 0,68 & 114,5 & 311,1 & 9,4 \\
\hline \multicolumn{5}{|c|}{ Отава } \\
\hline St. Манчаары & 0,49 & 140,0 & 289,0 & 9,8 \\
\hline K 1 & 0,68 & 147,2 & 313,0 & 9,4 \\
\hline K 2 & 0,67 & 140,2 & 302,5 & 9,6 \\
\hline K 7 & 0,62 & 134,9 & 325,0 & 9,1 \\
\hline K 12 & 0,65 & 104,3 & 335,2 & 8,9 \\
\hline K 18 & - & - & - & - \\
\hline
\end{tabular}


кормовым единицам при основном укосе выделились все сортообразцы $(0,68-0,70$ кг), стандарт Манчаары 0,49 кг; по переваримому протеину номера К 1, K 2 (149,6 г/кг, 162,5 г/кг корма), стандарт Манчаары 141,1 г/кг; по обменной энергии К 1 - 9,8 и К 2 - 10,0 МДж, стандарт 9,7 МДж В отаве по кормовым единицам также все сортообразцы и по переваримому протеину К 1, К 2 (147,2 и 140,2 г/кг), стандарт 140,0 г/кг (табл. 3).

\section{Выводы}

Из проведенных исследований за 2018-2020 гг. по сумме четырех укосов наибольшая продуктивность зе-

\section{ЛИТЕРАТУРА}

1. Шамсутдинов 3. Ш. Адаптивная система селекции кормовых растений (биоценотический подход). Издательство МГОУ. 2007. 224 c.

2. Косолапов В. М., Пилипко С.В., Костенко С.И. Новые сорта кормовых культур - залог успешного развития кормопроизводства. Достижение науки и техники АПК. 2015; 29(4): С. $35-37$.

3. Пилипко С.В. Достижения и перспективы селекции кормовых культур. Научное обеспечение селекции и семеноводства сельскохозяйственных культур. Самара: ООО «Книга", 2013. - C. $224-228$.

4. Евсеева Г. В. Особенности формирования многолетних злаковых травостоев для пастбищного использования в условиях Карелии. Кормопроизводство. 2017; (2): 3 - 8.

5. Кашеваров Н. И., Полюдина Р. И., Рожанская О. А. Селекционные достижения для кормопроизводства Сибири. Кормопроизводство. - 2012; ( 2): $38-45$.

6. Полюдина Р. И., Рожанская О. А., Потапов Д. А., Ланин В. А. Создание сортов кормовых культур в Сибири. Сибирский вестник сельскохозяйственной науки.2015 (2). 49 - 57.

7. Кадоркина В. Ф. Подбор исходного материала для селекции лом-коколосника ситникового на юге Средней Сибири. Кормо-производство. 2018; (9): С.38 - 41.

8. Кадоркина В. Ф., Шевцова М. С. Фитоценотическая парадигма в селекции ломкоколосника ситникового на юге Средней Сибири. Аграрная наука. 2019; (4): С. 58 - 61.

9. Косолапов В. М., Костенко С. И., Пилипко С. В., Клочкова В. С., Костенко Н. Ю., Малюженец Е. Е., Разгуляева Н. В., Кулешов Г. Ф., Пуца Н. М. Методические указания по селекции многолетних злаковых трав. СПб Издательство РГАУ МСХА. 2012. $53 \mathrm{c}$.

10. Гончаров П.Л., Гончаров Н.П. Методические основы селекции растений. Новосибирск. 1999. - 308 с.

11. Гончаров П. Л., Гончаров Н. П. Методические основы селекции растений. Изд-во Новосиб. ун-та. 2004. -312 с.

12. Шатский И. М., Иванов И. С., Переправо Н. И., Золотарев В. Н., Сапрыкина Н. В., Лабинская Р. М., Степанова Г. В., Георгиади Н. И., Тарасенко Н. Ф. Селекция и семеноводство многолетних трав в Центрально-Черноземном регионе России. Научное издание ОАО «Воронежская областная типография. 2016. - 236 с.

13. Доспехов Б.А. Методика полевого опыта с основами статистической обработки результатов исследования. Агропромиздат - 5-е изд.перераб. и доп. 1985. - 351 с.

14. Севостьянов В. К. Решая задачи эффективного и экологически безопасного ведения сельскохозяйственного производства в аридной зоне Алтае-Саянского экорегиона. Абакан, типография ООО Фирма «Март». 2007. - 88 с.

\section{ОБ АВТОРАX:}

Кадоркина Вера Федоровна, ФГБНУ НИИАП Хакасии, руководитель группы кормопроизводства селекции и семеноводства

Шевцова Мария Сергеевна, кандидат сельскохозяйственных наук, ФГБНУ НИИАП Хакасии, научный сотрудник группы кормопроизводства, селекции и семеноводства леной массы отмечена у К 1, К 2, К 3, К 5, К 6, К 9, К 18 -

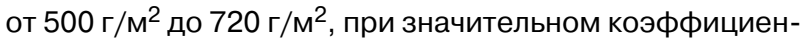
те вариации от 41,68-55,60\%.

В зависимости от кратности скашивания ломкоколосника ситникового установлено, что после четырехкратного скашивания высокую мощность куста имели номера - K 1, K 2, К 3, К 5, K 6, K 9, K 18 от 3,6 до 4,6 балла.

По кормовым единицам, переваримому протеину и обменной энергии выделились К 1, K 2 (0,69 кг корма и 0,67-0,68 кг, стандарт 0,49); (149,6, 162,5 г/кг корма и 140,2-147,2, стандарт 140,0 г/кг корма) и $(9,8-$ 10,0 МДж, стандарт Манчаары 9,7 МДж).

\section{REFERENCES}

1. [Shamsutdinov Z. S. Adaptive system of selection of forage plants (biocenotic approach). Moscow State University Publishing House. 2007. 224 p. (In Russ.)]

2. [Kosolapov V. M., Pilipko S. V., Kostenko S. I. New varieties of forage crops-the key to the successful development of forage production. Achievement of agricultural science and technology. 2015; 29(4): pp. 35-37(In Russ.)]

3. [Pilipko S. V. Achievements and prospects of breeding forage crops. Scientific support of selection and seed production of agricultural crops. Samara: LLC "Kniga", 2013. - pp. 224 - 228 (In Russ.)]

4. [Evseeva G. V. Features of the formation of perennial grass stands for pasture use in the conditions of Karelia. Feed production. 2017 ( 2 ): 3 - 8 (In Russ.)]

5. KKashevarov N. I., Polyudina R. I., Rozhanskaya O. A Selection achievements for feed production in Siberia. Feed production. - 2012; ( 2): 38 - 45 (In Russ.)]

6. [Polyudina R. I., Rozhanskaya O. A., Potapov D. A., Lanin V. A. Creation of forage crop varieties in Siberia. Siberian Bulletin of Agricultural Science. 2015 (2). 49 - 57 (In Russ.)].

7. [Kadorkina V.F. Selection of the source material for the selection of shitnikovy scrap in the south of Central Siberia. Feed production. 2018; (9): Page 38 - 41. (In Russ.)] https://doi. org/10.25685/KRM.2018.2018.17311

8. [Kadorkina V.F., Shevtsova M.S. The fitocenotic paradigm in the selection of the sitnikovy slab grate in the south of Central Siberia. Agrarian Science. 2019; (4): S. 58 - 61 (In Russ.)] https:// doi.org/10.32634/0869-8155-2019-324-4-58-61

9. [Kosolapov V. M., Kostenko S. I., Pilipko S. V., Klochkova V. S., Kostenko N. Yu., Malyuzhenets E. E., Razgulyaeva N. V., Kuleshov G. F., Putsa N. M. Methodological guidelines for the selection of perennial grasses. St. Petersburg Publishing House RGAU MSHA. 2012. 53 p. (In Russ.)]

10. [Goncharov P.L., Goncharov N.P. Methodological foundations of plant breeding. Novosibirsk. 1999. - 308 p 9 (In Russ.)]

11. [Goncharov P. L., Goncharov N. P. Methodological foundations of plant breeding. Publishing house Novosib. un-ta. 2004. $-312 \mathrm{p}$ (In Russ.)]

12. [Shatsky I.M., Ivanov I.S., Perekrovo N.I., Zolotarev V.N., Saprykina N.V., Labinskaya R.M., Stepanova G.V., Georgiadi N.I., Tarasenko N.F. Selection and seed production of perennial herbs in the Central Black Earth region of Russia. Scientific publication of OJSC Voronezh Regional Printing House. 2016. - 236 p (In Russ.)]

13. [Armor B.A. Field experience methodology with the basics of statistical processing of research results. Agro-industrial publishing house - 5th ed. Perererab. and addendum. 1985. - 351 $\mathrm{p}$ (In Russ.)]

14. [Sevostyanov V.K. Solving the problems of efficient and environmentally safe agricultural production in the arid zone of the Altai-Sayan ecoregion. Abakan, printing house LLC Firm "March." 2007. - 88 p. (In Russ.)]

\section{ABOUT THE AUTHORS}

Kadorkina Vera Fedorovna, Head of the group of feed production breeding and seed production, FGBNU NIIAP of Khakassia Shevtsova Maria Sergeevna, Candidate of Agricultural Sciences, National Research University of the Institute of Agricultural Sciences of Khakassia, researcher of the group of feed production, breeding and seed production 